\title{
Influence of Yarns of Single Tricot Stitch on Hand of Knitted tapes for Fasteners
}

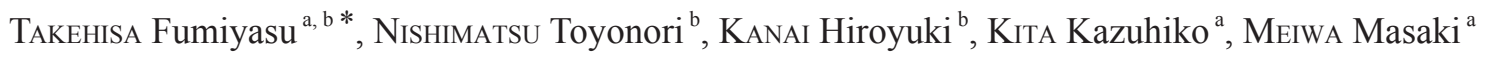 \\ ${ }^{a}$ YKK Co., Ltd., 200, Yoshida, Kurobe, Toyama 938-8601, Japan \\ ${ }^{\mathrm{b}}$ Faculty of Textile Science and Technology, Shinshu University, 3-15-1 Tokida, Ueda, Nagano 386-8567, Japan
}

Received 30 September 2016; accepted for publication 8 February 2017

\begin{abstract}
In this study, we investigated how the yarn used in single tricot stitch affects the hand evaluation of knitted tapes for fasteners. For this purpose, experimental tapes that differed only in the yarn of the single tricot stitch were evaluated using the paired comparison method and their mechanical properties were measured. Furthermore, we compared the results with the effect of yarns of single satin stitch on hand evaluation reported in previous studies. The results are as follows. (1) Knitted tapes that differed only in the yarn of the single tricot stitch affected the hand evaluations of "dry" and "easy to slide". (2) There was no significant correlation between the mean preference scores of "dry" and "easy to slide" and the friction property and roughness property. (3) Knitted tapes using a yarn with a high crimp recovery rate for single tricot stitch were evaluated as "dry", and knitted tapes using a yarn with a low crimp recovery rate for single tricot stitch were evaluated as "not dry". (4) Knitted tapes using a yarn with a high heating shrinkage tension for single tricot stitch were evaluated as "easy to slide", and knitted tapes using a yarn with a low heating shrinkage tension for single tricot stitch were evaluated as "not easy to slide".
\end{abstract}

Key Words : Fastener, Single tricot stitch, Knitted tape, Hand, Mechanical properties

\section{シングルトリコット編構造糸がファスナ用編テープの 手触りに与える影響}

\author{
竹久文康 ${ }^{\mathrm{a}, \mathrm{b}}$ *, 西松豊典 ${ }^{\mathrm{b}}$, 金井博幸 ${ }^{\mathrm{b}}$, 喜多和彦 ${ }^{\mathrm{a}}$, 明和正樹 ${ }^{\mathrm{a}}$ \\ ${ }^{\mathrm{a}}$ YKK 株式会社, ${ }^{b}$ 信州大学繊維学部
}

\section{1. 緒 言}

スライドファスナ（以下, ファスナという）は, 衣服, 鞄, 靴, 寝具などの繊維製品に用いられ, 基本性能として強度や 耐久性などが必要とされている。近年, 感性価值を向上させ た繊維製品が多くなるにつれて, 繊維製品に縫製されている ファスナにおいても感性価值を向上させることが要求される ようになった，特に，婦人服に用いるファスナ用編テープ（互 いに噛み合う務歯を取り付けるための細幅なたて編布）の触 感が重視されている。

筆者らは, 先行研究においてファスナ用編テープを構成す
る 3 種類のたて編組織のうち, シングルサテン編の編成に使 用する糸 (以下, シングルサテン編構造糸と呼ぶことにする)

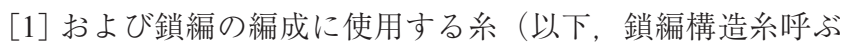
ことにする）[2] がファスナ用編テープの手触りに与える影 響を明らかにした。しかし, シングルトリコット編の編成に 使用する糸（以下，シングルトリコット構造糸と呼ぶことに する）がファスナ用編テープの手触りに与える影響について は検討していない.

シングルトリコット編（シングルデンビ編とも言う）は 1 枚筬のたて糸を隣接する針に交互にラッピングさせるたて編 の基本組織であるが，シングルトリコット編だけでは編地が

* 連絡先：YKK 株式会社 工機技術本部 938-8601 富山県黒部市吉田 200 E-mail : f-takehisa@ykk.co.jp, Tel : +81-765-54-8825, Fax : +81-765-54-8818 
薄く, カーリングを生じて安定性が悪いため単独で用いられ ることはほとんどなく $[3]$, 多くの場合は他の組織と併用さ れる。フファナ用編テープにおいても，シングルサテン編お よび鎖編と併用され，編テープの幅寸法の安定化や必要強度 の確保に欠かすことができないたて編組織の一つとして用い られている。

トリコット編に関する研究は数多く報告され，寺崎らは筬 の移動距離が異なるたて編布の圧縮特性は糸密度よりも編組 織から受ける影響が大きく，筬の移動距離が大きい編組織ほ ど厚くて圧縮率が大きいことを報告している [4]，川端は， たて編布の引張り特性を糸の曲げ効果領域と糸の伸び効果領 域に分けて解析する理論的誘導法を報告している [5]。柳川 らは, 編布の構造定数と糸の力学特性より 2 枚筬トリコット 編布のせん断特性を理論的に誘導し [6]，糸の引張り特性と 圧縮特性を理論に加えることで精度よく予測できること [7]， 編布の構造定数と糸の曲げ剛性およびねじり剛性より2 枚筬 トリコット編布の曲げ特性を理論的に誘導し [8], 繊維間お よび糸間の摩擦特性を理論に加えることで精度よく予測でき ることを報告している [9].しかし，これらの研究は 1 枚筬 あるいは 2 枚筬で編成されるトリコット編布の力学特性に関 する研究であり，3 枚筬で編成されるファスナ用編テープに おけるシングルトリコット編構造糸が手触りに与える影響に ついては報告されていない.

そこで, 本研究ではシングルトリコット編構造糸がファス
ナ用編テープの手触りに与える影響を明らかにするために， 先行研究 [1,2] で用いた素材と繊度が同一で製造条件が異な る 5 種類のポリエステルマルチフィラメント糸を用いて, シ ングルトリコット編構造糸だけが異なる 5 種類のファスナ用 編テープを試料として作製した。そして，被験者に各試料の 手触りを評価させるとともに, 各試料の力学特性を測定して 手触り評価量と力学特性との相関関係を検討し, シングルト リコット編構造糸がファスナ用編テープの手触り評価に与え る影響を考察した。

\section{2. 試料および実験方法}

\section{1 試料}

婦人服に用いるファスナ用編テープは, 毎コース同一針に 糸を巻きつけた鎖編 (Fig. 1 (a)に太線で図示), 隣接する針 へ交互に糸を巻きつけたシングルトリコット編（Fig. 1 (b) に太線で図示）および 2 本おいた次の針へ交互に糸を巻きつ けたシングルサテン編（Fig. 1 (c) に太線で図示）の 3 種類 のたて編組織が毎コース同時に編成される.

本研究では, ファスナ用編テープを構成する 3 種類のたて 編組織のうち，シングルトリコット編構造糸がファスナ用編 テープの手触りに与える影響を明らかにすることを目的と して，シングルトリコット編構造糸だけが異なる 5 種類の

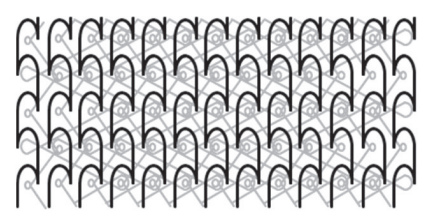

(a)

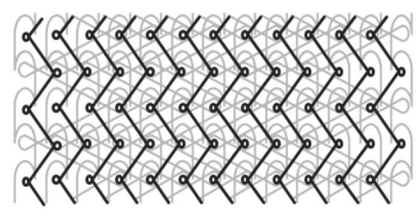

(b)

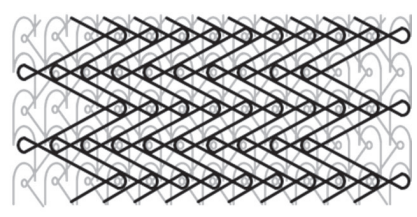

(c)

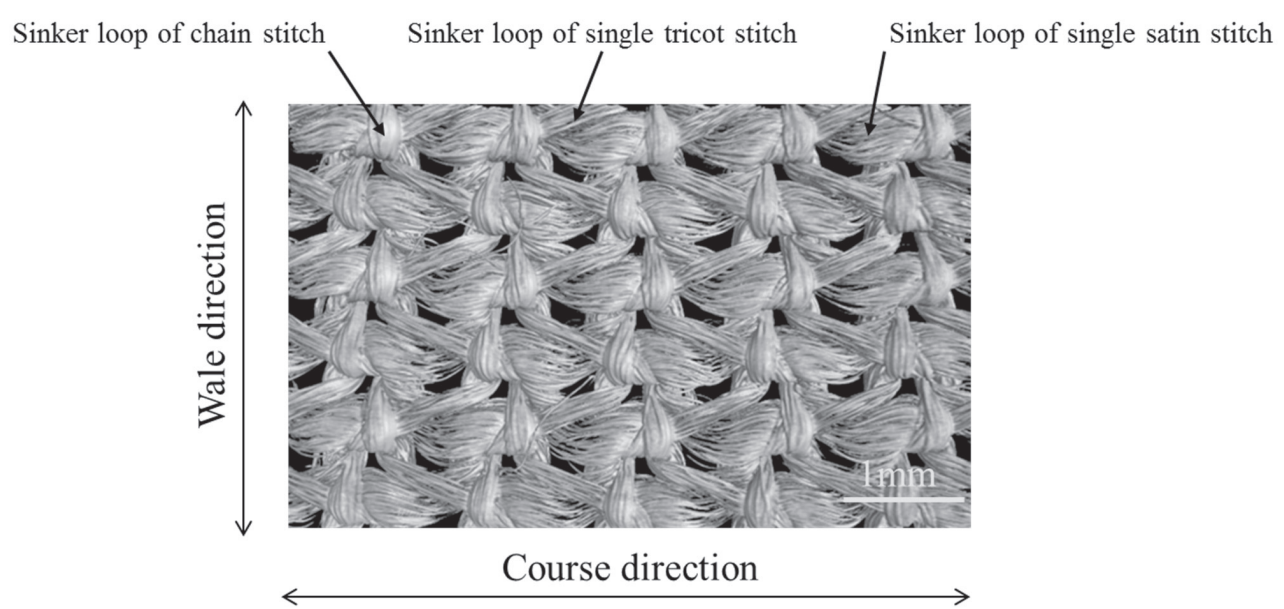

(d)

Fig. 1 Details of warp-knitting stitch of knitted tape.
(a) Chain stitch.
(b) Single tricot stitch.
(c) Single satin stitch.
(d) X-ray CT image of specimen- $\mathrm{T}_{1}$. 
Table 1 Details of polyester multifilament yarns[1,2].

\begin{tabular}{l|c|c|c|c|c}
\hline & yarn-1 & yarn-2 & yarn-3 & yarn-4 & yarn-5 \\
\hline \hline Material & \multicolumn{5}{|c}{ PET } \\
\hline Apparent fineness (dtex) & \multicolumn{7}{|c}{110} \\
\hline Spinning process & \multicolumn{2}{|c|}{ FDY } & \multicolumn{2}{c}{ DTY } \\
\hline Filament number & 36 & 24 & 24 & 34 & 72 \\
\hline Tensile strength (cN/dtex) & 4.02 & 5.64 & 6.05 & 3.75 & 3.98 \\
\hline Elongation percentage (\%) & 36.7 & 23.3 & 18.6 & 24.0 & 24.2 \\
\hline Crimp recovery rate (\%) & 0.5 & 0.4 & 0.4 & 17.8 & 14.8 \\
\hline Dry heating dimensional change ratio at $170^{\circ} \mathrm{C}(\%)$ & 8.3 & 6.2 & 11.0 & 4.4 & 6.2 \\
\hline Dry heating shrinkage tension at $170^{\circ} \mathrm{C}(\mathrm{cN} / \mathrm{dtex})$ & 0.28 & 0.14 & 0.23 & 0.06 & 0.12 \\
\hline
\end{tabular}

試料（ $\left.\mathrm{T}_{1}, \mathrm{~T}_{2}, \mathrm{~T}_{3}, \mathrm{~T}_{4}, \mathrm{~T}_{5}\right)$ を作製した。 シングルトリコッ 卜編構造糸に用いた糸は, Table 1 に示す先行研究 [1,2] で用 いた素材と繊度が同一で製造条件が異なる 5 種類のポリエス テルマルチフィラメント糸（yarn-1, yarn-2, yarn-3, yarn-4, yarn-5）である。また，各試料のシングルサテン編構造系お よび鎖編構造糸に用いた糸は yarn-1 である。シングルトリ コット編構造糸だけが異なる 5 種類の試料 $\left(\mathrm{T}_{1}, \mathrm{~T}_{2}, \mathrm{~T}_{3}, \mathrm{~T}_{4}\right.$, $\mathrm{T}_{5}$ ) における各編組織と糸との関係を Table 2 に示す。試料は, たて編機 (ゲージ数 20 , 編針 1 列, 筬数 3 枚) を用いて編成し, 形態を安定させる目的で編成後にヒートセット処理を $170 \pm$ $5{ }^{\circ} \mathrm{C}$ で 30 秒間実施し, 室温 $25 \pm 44^{\circ} \mathrm{C}$, 湿度 $65 \pm 5 \% \mathrm{RH}$ の環境 で作製した。

本実験結果を考察するために用いた比較用試料は, 先行研 究 [1] で作製したシングルサテン編構造糸だけが異なる 5 種 類の試料 $\left(\mathrm{S}_{1}, \mathrm{~S}_{2}, \mathrm{~S}_{3}, \mathrm{~S}_{4}, \mathrm{~S}_{5}\right)$ である。これらの試料におけ る各編組織と糸との関係を Table 3 に示す. Table 3 に示すよ うに, 各試料 $\left(\mathrm{S}_{1}, \mathrm{~S}_{2}, \mathrm{~S}_{3}, \mathrm{~S}_{4}, \mathrm{~S}_{5}\right)$ はシングルサテン編構造 糸にそれぞれ yarn-1, yarn-2, yarn-3, yarn-4, yarn-5を, 鎖 編構造系およびシングルトリコット編構造糸に yarn-1 を用い て編成した. 各試料 $\left(\mathrm{S}_{1}, \mathrm{~S}_{2}, \mathrm{~S}_{3}, \mathrm{~S}_{4}, \mathrm{~S}_{5}\right)$ は, 本研究と同一 条件で編成したのちヒートセット処理を実施した。

\section{2 官能検査方法}

手触りを評価するための形容語は, 温冷感を表す「あたた かい」, 乾湿感を表す「しっとりした, さらっとした」, 粗滑 感を表す「滑らかな, 平らな, 滑りやすい」, 厚さ感を表す「薄 い」, 伸長感を表す「伸びない」, 硬軟感を表す「やわらかい, しなやかな, 弾力がある」の 11 種類の物理形容語および婦 人服に用いるファスナに必要な「さわやかな, はりがない, こしがない, 控えめな, 高級感がある, 肌触りが良い, 肌に なじむ」の 7 種類のイメージ形容語を選定し, 合計 18 種類 の形容語を選定した $[1,2]$.

物理形容語の手触り評価試技は, 視覚による影響 [11]を 排除するために目を閉じた状態で, ファスナ用編テープが約 $13 \mathrm{~mm}$ と細幅であることを考慮して, Fig. 2 に示すように手 指だけで評価する試技を設定した $[1,2]$.

(1)温冷感を表す「あたたかい」は, Fig. 2 (a) に示すように 利き手の人差し指と中指を試料のシンカーループ面に「押 し当てて」評価.

(2)乾湿感を表す「しっとりした，さらっとした」および粗滑 感を表す「滑らかな, 平らな, 滑りやすい」は, Fig. 2 (a) に示すように利き手の人差し指と中指で試料のシンカー ループ面を「滑らせて」評価.

(3)厚さ感を表す「薄い」は, Fig. 2 (b) に示すように利き手 の親指と人差し指で試料を厚さ方向に「つまんで」評価.

Table 2 Knitted tapes that differd only in the yarn of single tricot stitch.

\begin{tabular}{l|c|c|c|c|c}
\hline & $\mathrm{T}_{1}$ & $\mathrm{~T}_{2}$ & $\mathrm{~T}_{3}$ & $\mathrm{~T}_{4}$ & $\mathrm{~T}_{5}$ \\
\hline \hline Chain stitch & \multicolumn{4}{|c}{ yarn-1 } \\
\hline Single tricot stitch & yarn-1 & yarn-2 & yarn-3 & yarn-4 & yarn-5 \\
\hline Single satin stitch & \multicolumn{5}{|c}{ yarn-1 } \\
\hline
\end{tabular}

Table 3 Knitted tapes that differd only in the yarn of single satin stitch[1].

\begin{tabular}{|c|c|c|c|c|c|}
\hline & $\mathrm{S}_{1}$ & $\mathrm{~S}_{2}$ & $\mathrm{~S}_{3}$ & $\mathrm{~S}_{4}$ & $\mathrm{~S}_{5}$ \\
\hline Chain stitch & \multicolumn{5}{|c|}{ yarn-1 } \\
\hline Single tricot stitch & \multicolumn{5}{|c|}{ yarn-1 } \\
\hline Single satin stitch & yarn-1 & yarn-2 & yarn-3 & yarn-4 & yarn-5 \\
\hline
\end{tabular}




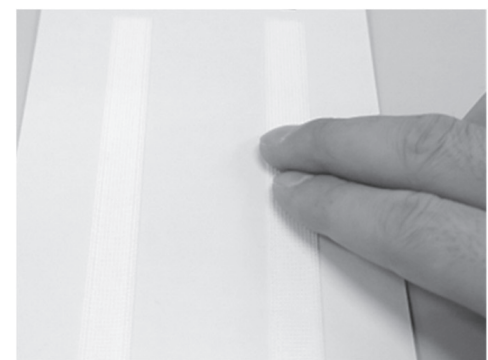

(a)

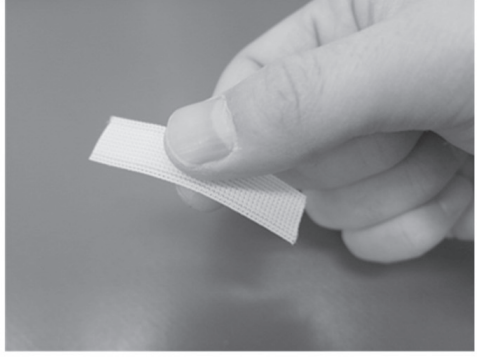

(b)

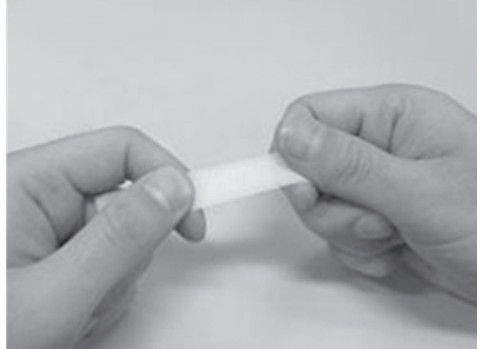

(c)

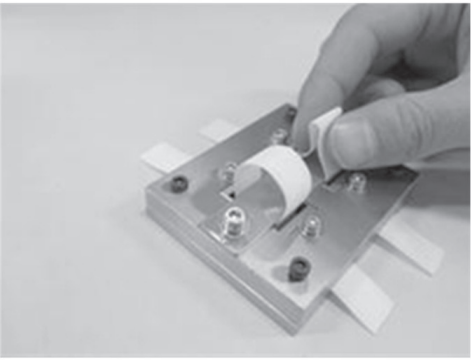

(d)

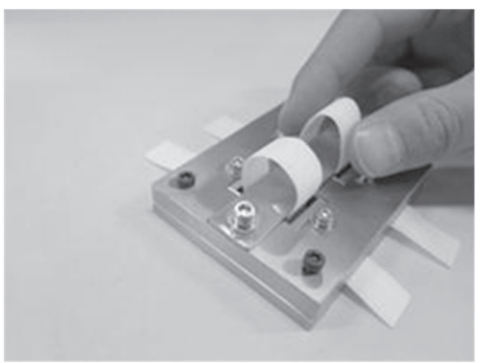

(e)

Fig. 2 Finger motion in sensory evaluation[1,2].

(a) Press/Slide, (b) Pinch, (c) Stretch, (d) Bend, (e) Release

(4)伸長感を表す「伸びない」は, Fig. 2 (c) に示すように両 手の親指と人差し指で試料をウェール方向に「伸ばして」 評価.

(5)硬軟感を表す「やわらかい」は, Fig. 2 (d) に示すように 利き手の親指と人差し指で試料をウェール方向に「挟んで」 評価.

(6)硬軟感を表す「しなやかな，弾力がある」は，Fig. 2 (e) に示すように利き手の親指と人差し指で試料をウェール方 向に挟んだあとに「戻して」評価.

(7)イメージを表す「さわやかな，はりがない，こしがない， 控えめな，高級感がある，肌触りが良い，肌になじむ」は， 試技(1)〜 (6)を用いて総合的に評価.

手触り評価にはシェッフェの一対比較法 (中屋の変法) [10] を用いて，18 種類の各形容語について 7 段階尺度（非常に; \pm 3 点, かなり； \pm 2 点, やや ; \pm 1 点, どちらともいえない； 0 点）で評価した。

試料は婦人服に用いるファスナ用編テープを想定したの で，手触りを評価する被験者は女性とし，手触り品質検査の 専門家 13 名のうち先行研究 $[1,2]$ において手触り判定能力 を有すると認められた 9 名（20 代; 3 名， 30 代; 3 名，40 代； 1 名, 50 代 ; 2 名）とした.

試料は恒温恒湿室（室温 $23 \pm 2^{\circ} \mathrm{C}$, 湿度 $50 \pm 4 \%$ R.H.）に 24 時間放置した後，恒温恒湿室内で官能検査を実施した。

\section{3 ファスナ用編テープのカ学特性の測定}

官能検査による手触り評価量を客観評価するために, 各試 料の力学特性（引張り特性, 曲げ特性, 圧縮特性, 摩擦特性, 粗さ特性）を測定した。測定用試料は 1 試料につき 10 箇所
から採取して, 各試料を 1 回ずつ合計 10 回測定した。試料 は恒温恒湿室（室温 $23 \pm 2^{\circ} \mathrm{C}$, 湿度 $50 \pm 4 \%$ R.H. ) に 24 時間放 置した後, 恒温恒湿室内で各力学特性を測定した。 各力学特 性の測定方法は以下のとおりである。

\section{（1）引張り特性}

自動化引張り ・ せん断試験機（KES-FB1-AUTO-A，カトー テック(株)製) を用いて, 試料 (幅 $1.3 \mathrm{~cm} \times$ 試料長 $20 \mathrm{~cm}$ ) のウェー ル方向に対する引張特性（1)引張り直線性 (LT), (2)引張り 仕事量（WT), (3)引張りレジリエンス (RT), (4)最大伸び率 (EMT)）を測定した。測定条件は, 引張り速度 $0.05 \mathrm{~mm} / \mathrm{sec}$, 単位幅あたりの最大荷重 $500 \mathrm{gf} / \mathrm{cm}$ ，チャック間距離 $50 \mathrm{~mm}$ と して, 試料のシンカーループ面を上, 編始め方向が稼働アー ム側になるように設置して測定した.

\section{（2）曲げ特性}

多目的純曲げ試験機（KES-FB2-S，カトーテック(株製）を 用いて，試料（幅 $1.3 \mathrm{~cm} \times$ 試料長 $7 \mathrm{~cm}$ ) のウェール方向に対 する曲げ特性（1)表曲げ剛性（B+；曲率 $0.5 \sim 1.5 \mathrm{~cm}^{-1}$ におけ る曲げ剛性), (2)裏曲げ剛性（B-；曲率 $-0.5 \sim-1.5 \mathrm{~cm}^{-1}$ におけ る曲げ剛性), (3)平均曲げ剛性 (BM； B+と B-の平均), (4) 表曲げヒステリシス $\left(2 \mathrm{HB}+\right.$; 曲率 $1.0 \mathrm{~cm}^{-1}$ における曲げヒス テリシス), (5)裏曲げヒステリシス (2HB- ; 曲率 $-1.0 \mathrm{~cm}^{-1} に$ おける曲げヒステリシス), (6)平均曲げヒステリシス (2HBM; $2 \mathrm{HB}+$ と $2 \mathrm{HB}-$ の平均)）を測定した。測定条件は，最大曲げ 曲率 $\pm 2.5 \mathrm{~cm}^{-1}$ として，表曲げ時にニードルループ面を内側， 編終わり方向が稼働アーム側になるように設置して測定し 
た

\section{（3）圧縮特性}

ハンディー圧縮試験機（KES-G5，カトーテック(株)製）を 用いて，試料（幅 $1.3 \mathrm{~cm} \times$ 試料長 $10 \mathrm{~cm}$ ）の厚さ方向に対する 圧縮特性（1)圧縮直線性 (LC), (2)圧縮仕事量 (WC), (3)圧 縮レジリエンス $(\mathrm{RC})$, (4)初期厚さ $\left(\mathrm{T}_{0}\right.$; 圧力 $0.5 \mathrm{gf} / \mathrm{cm}^{2}$ 時に おける試料厚さ), (5)最大圧縮時の厚さ $\left(\mathrm{T}_{\mathrm{M}}\right.$; 最大圧力 $25 \mathrm{gf} /$ $\mathrm{cm}^{2}$ 時における試料厚さ)）を測定した。測定条件は, 円形 圧縮板の面積 $1 \mathrm{~cm}^{2}$, 圧縮速度 $0.02 \mathrm{~mm} / \mathrm{sec}$, 最大圧力 $25 \mathrm{gf} / \mathrm{cm}^{2}$ （被験者がファスナ用編テープを「つまむ」時の平均圧力 [1]） として，シンカーループ面が圧縮板側になるように設置して 測定した。

\section{（4）摩擦特性}

摩擦感テスター (KES-SE-SR-U, カトーテック(株製) を用 いて, 試料（幅 $1.3 \mathrm{~cm} \times$ 試料長 $5 \mathrm{~cm}$ ) のシンカーループ面の 摩擦特性 (1)平均摩擦係数 (MIU), (2)摩擦係数の平均偏差 $(\mathrm{MMD}))$ を, 摩擦感テスターから出力されたアナログ電圧 をオシロスコープ（DL850, 横河電機株製）へサンプリング 周波数 $5 \mathrm{kHz}$ で入力した電圧から算出し, 試料の編始め方向 から編終わり方向および編終わり方向から編始め方向の摩擦 係数を測定して, 両者の平均值を測定値とした。摩擦子は先 行研究 [1] と同様にアクリル製樹脂のフレームに発泡シリコ ンゴム（信越ポリマー(株製）を取り付けた摩擦子を用いた。 測定条件は, 摩擦試験速度 $0.5 \mathrm{~cm} / \mathrm{sec}$, 静荷重 $2.5 \mathrm{gf}$, 測定距 離は $3 \mathrm{~cm}$ で解析距離は中間の $2 \mathrm{~cm}$ とした。

\section{(5) 粗さ特性}

摩擦感テスター（KES-SE-SR-U，カトーテック(株)製）を用 いて, 試料（幅 $1.3 \mathrm{~cm} \times$ 試料長 $20 \mathrm{~cm}$ ）のシンカーループ面の 粗さ特性 (表面粗さ $(\mathrm{SMD})$ ) を, 摩擦感テスターから出力 されたアナログ電圧をオシロスコープ (DL850, 横河電機(株) 製）へサンプリング周波数 $5 \mathrm{kHz}$ で入力した電圧から算出し, 試料の編始め方向から編終わり方向および編終わり方向から 編始め方向の粗さ特性を測定して, 両者の平均值を測定值 とした。測定条件は, 粗さ試験速度 $0.5 \mathrm{~cm} / \mathrm{sec}$, 静荷重 $10 \mathrm{gf}$, 測定距離は $3 \mathrm{~cm}$ で解析距離は中間の $2 \mathrm{~cm}$ とした。

\section{3．実験結果および考察}

\section{$3.1\lceil$ 手触り」官能検査結果}

シングルトリコット編構造糸がファスナ用編テープの手触 り評価に与えた影響を明らかにするために，シェッフェの一 対比較法（中屋の変法）の解析手法 [10]に従って, 各形容 語の手触り評価結果について主効果（試料に対して被験者 全体が持つ平均的な嗜好度), 嗜好度の個人差（試料に対し て被験者個人が持つ嗜好度）および組合せ効果（試料の組合 せによる効果）の各要因について分散分析を行った結果を Table 4 に示す。なお, Table 4 に示す值は各要因の不偏分散 を誤差の不偏分散で割った $\mathrm{F}_{0}$ 值である。

Table 4 より, 主効果がみられ，かつ組合せ効果がみられな かった形容語は, 18 種類の形容語のうち乾湿感を表す「さらっ とした」および粗滑感を表す「滑りやすい」の 2 種類であった.

Table 4 Results of variance ratio (F0) for mean preference scores of each adjective.

\begin{tabular}{l|c|c|c}
\hline & Main effect & Individual effect & Combination effect \\
\hline \hline Warm & 1.51 & $2.11^{* *}$ & $2.40^{*}$ \\
\hline Shittori & 2.29 & 1.28 & 0.59 \\
\hline Dry & $2.96^{*}$ & 1.03 & 0.53 \\
\hline Smooth & 1.51 & 1.10 & 1.12 \\
\hline Flat & 0.74 & 0.59 & 0.98 \\
\hline Easy to slide & $3.49^{*}$ & $2.72 * *$ & 1.86 \\
\hline Thin & $7.25^{* *}$ & 1.34 & $2.75^{*}$ \\
\hline Not stretch & 1.40 & 0.50 & 0.43 \\
\hline Soft & 0.73 & 0.76 & 0.91 \\
\hline Flexible & 1.95 & 0.64 & 0.57 \\
\hline Elastic & 1.62 & 0.45 & 0.22 \\
\hline Refresh & 0.37 & 1.21 & 0.55 \\
\hline Not hari & 0.69 & 0.93 & 0.58 \\
\hline Not koshi & 0.76 & 0.97 & 0.64 \\
\hline Conservative & 0.31 & 1.01 & 0.57 \\
\hline High-class & 0.82 & 0.32 & 2.07 \\
\hline Good in touch & 1.14 & 1.31 & $2.30^{*}$ \\
\hline Comfortable on skin & 1.59 & 1.27 & $2.68 *$ \\
\hline & & $* * 1 \%$ significant, $* 5 \%$ significant
\end{tabular}


Table 5 Mean preference scores of "dry" and "easy to slide".

\begin{tabular}{c|c|c|c|c|c}
\hline & $\mathrm{T}_{1}$ & $\mathrm{~T}_{2}$ & $\mathrm{~T}_{3}$ & $\mathrm{~T}_{4}$ & $\mathrm{~T}_{5}$ \\
\hline \hline \multirow{2}{*}{ Dry } & 0.29 & 0.27 & -0.07 & -0.29 & -0.20 \\
\cline { 2 - 5 } & $\left(* * \mathrm{~T}_{4}\right),\left(* \mathrm{~T}_{5}\right)$ & $\left(* * \mathrm{~T}_{4}\right),\left(* \mathrm{~T}_{5}\right)$ & & $\left(* * \mathrm{~T}_{1,2}\right)$ & $\left(* \mathrm{~T}_{1,2}\right)$ \\
\hline \multirow{2}{*}{ Easy to slide } & 0.22 & -0.31 & 0.33 & 0.04 & -0.29 \\
\cline { 2 - 6 } & $\left(* \mathrm{~T}_{2,5}\right)$ & $\left(* * \mathrm{~T}_{3}\right),\left(* \mathrm{~T}_{1}\right)$ & $\left(* * \mathrm{~T}_{2,5}\right)$ & & $\left(* * \mathrm{~T}_{3}\right),\left(* \mathrm{~T}_{1}\right)$ \\
\hline
\end{tabular}

$* * 1 \%$ significant, $* 5 \%$ significant

このことから，シングルトリコット編構造糸は，乾湿感を表 す「さらっとした」および粗滑感を表す「滑りやすい」の手 触り評価に影響を与えることがわかった。

乾湿感を表す「さらっとした」および粗滑感を表す「滑り やすい」について, 各試料の平均嗜好度 [10]を算出した結 果およびヤードスティック [10］を用いて試料間の有意差を 検定した結果を Table 5 に示す.

Table 5 より, 乾湿感を表す「さらっとした」の評価では, シングルトリコット編構造糸に yarn-1 および yarn-2 を用い た試料 $\mathrm{T}_{1}$ および試料 $\mathrm{T}_{2}$ は，シングルトリコット編構造糸に yarn-4 およびyarn-5 を用いた試料 $\mathrm{T}_{4}$ および試料 $\mathrm{T}_{5}$ よりも平 均嗜好度が大きく「さらっとした」と評価されたことがわかっ た。これは, Table 1 より yarn-1 およびyarn-2 はy yarn-4 およ
び yarn-5よりも合成繊維のかさ高性を表す伸縮復元率（JIS L 1013）が小さいので見掛け太さが小さくなり，被験者が試料 の表面に手指を滑らせたときにシングルトリコット編構造糸 に触れる面積が減少したので「さらっとした」と評価された と推測される

Table 5 より, 粗滑感を表す「滑りやすい」の評価では, シ ングルトリコット編構造糸にyarn-1 およびyarn-3 を用いた 試料 $\mathrm{T}_{1}$ および試料 $\mathrm{T}_{3}$ は, シングルトリコット編構造糸に yarn-2 および yarn-5 を用いた試料 $\mathrm{T}_{2}$ および試料 $\mathrm{T}_{5}$ よりも平 均嗜好度が大きく「滑りやすい」と評価されたことがわかっ た。これは, Table 1より yarn-1 およびyarn-3 は yarn-2 およ びyarn-5よりも乾熱収縮張力が大きいのでヒートセット処理 で編構造に差異が生じたと考えられる。被験者は編テープの

Table 6 Results of mechanical properties.

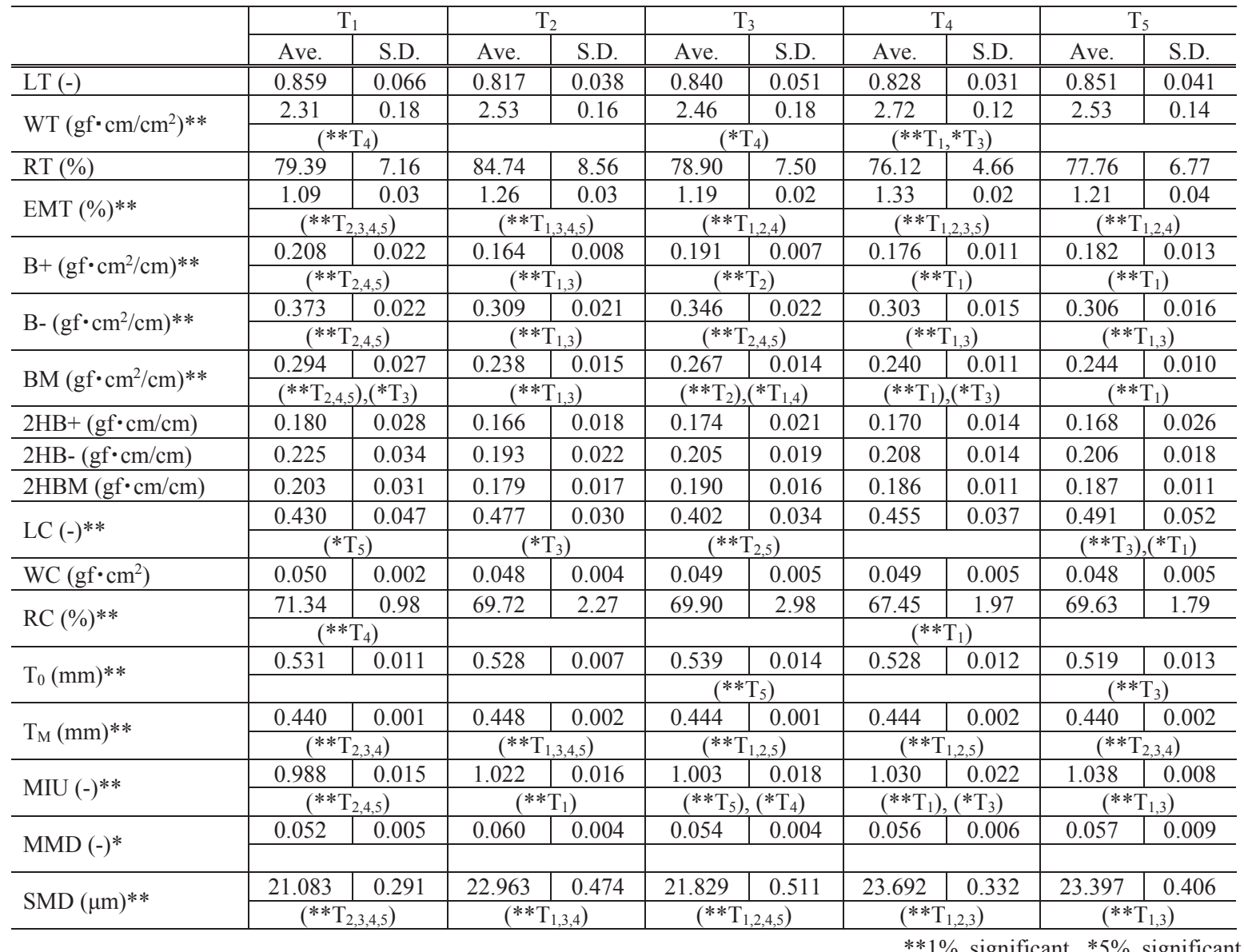


表面上に手指を滑らせて「滑りやすい」について評価したの で，表面粗さの差異を評価したと推測される.

\section{2 力学特性測定結果と「手触り」との関係}

各試料について測定した力学特性値の平均值および標準偏 差，各力学特性值において各試料間を分散分析した結果およ びシェッフェの手法で多重比較検定した結果を Table 6 に示 す. Table 6 に示す多重比較検定結果において試料差がみら れた 11 種類の力学特性值 (WT, EMT, B+, B-, BM, LC, $\left.\mathrm{RC}, \mathrm{T}_{0}, \mathrm{~T}_{\mathrm{M}}, \mathrm{MIU}, \mathrm{SMD}\right)$ と Table 5 に示す 2 種類の形容語 「さらっとした, 滑りやすい」の平均嗜好度との相関係数を Table 7 に示す.

Table 7 より, 乾湿感を表す「さらっとした」はどの力学特 性值とも相関がみられなかった。先行研究 [1] では, Table 3 に示すシングルサテン編構造糸だけが異なる 5 試料 $\left(\mathrm{S}_{1} \sim \mathrm{S}_{5}\right)$ について手触り官能検査および摩擦特性を本研究と同一条件 で測定した結果，シングルサテン編構造糸の伸縮復元率の 差異によって乾湿感を表す「さらっとした」に主効果 $\left(\mathrm{F}_{0}\right.$; $\left.25.95^{* *}\right)$ があり, 平均摩擦係数 (MIU) と負の相関 $\left(\mathrm{r}=-0.975^{* *}\right)$ がみられたと報告した。本研究においても，前節で述べたよ うにシングルトリコット編構造糸の伸縮復元率の差異によっ て乾湿感を表す「さらっとした」の手触り評価に影響を与え ると推測されたが，シングルトリコット編構造糸が異なる 5 試料において乾湿感を表す「さらっとした」は平均摩擦係数 (MIU) と有意な相関はみられなかった。そこで, 本研究で
Table 7 Correlation coefficients between mechanical properties and mean preference scores of "dry" and "easy to slide".

\begin{tabular}{l|c|c}
\hline & Dry & Easy to slide \\
\hline \hline WT & -0.734 & -0.367 \\
\hline EMT & -0.582 & -0.390 \\
\hline B + & 0.214 & 0.735 \\
\hline B- & 0.560 & 0.751 \\
\hline BM & 0.498 & 0.727 \\
\hline LC & -0.132 & $-0.962 * *$ \\
\hline RC & 0.764 & 0.211 \\
\hline $\mathrm{T}_{0}$ & 0.252 & 0.827 \\
\hline $\mathrm{T}_{\mathrm{M}}$ & 0.122 & -0.256 \\
\hline MIU & -0.645 & -0.762 \\
\hline SMD & -0.653 & -0.689 \\
\hline \multicolumn{2}{|c}{}
\end{tabular}

作製した Table 2 に示すシングルトリコット編構造糸だけが 異なる 5 試料および先行研究 [1] で作製したTable 3 に示す シングルサテン編構造糸だけが異なる 5 試料について, 乾湿 感を表す「さらっとした」の主効果の分散比 $\mathrm{F}_{0}$ 值および平 均摩擦係数 (MIU) の分散比 F 值を Table 8 に示す.

Table 8 より，シングルトリコット編構造糸だけが異なる 5 試料はシングルサテン編構造糸だけが異なる 5 試料よりも乾 湿感を表す「さらっとした」の主効果の分散比 $\mathrm{F}_{0}$ 值および 平均摩擦係数 (MIU) の分散比 $\mathrm{F}$ 值が小さいことがわかる. このことから，シングルトリコット編構造糸はシングルサテ

Table 8 Variance ratio $\left(\mathrm{F}_{0}\right)$ for mean preference scores of "dry" and variance ratio (F) for mean coefficient of friction (MIU) in knitted tapes that differd only in the yarn of single satin stitch or single tricot stitch.

\begin{tabular}{l|c|c}
\hline & $\begin{array}{c}\text { Knitted tapes that differed only in the yarn of } \\
\text { the single tricot stitch }\end{array}$ & $\begin{array}{c}\text { Knitted tapes that differed only in the yarn of } \\
\text { the single satin stitch[1] }\end{array}$ \\
\hline \hline F of main effect of "Dry" & $2.96^{*}$ & $25.95^{* *}$ \\
\hline F of MIU & $9.28^{* *}$ & $86.27 * *$ \\
\hline \multicolumn{2}{|c}{} & $* 1 \%$ significant, $* 5 \%$ significant
\end{tabular}

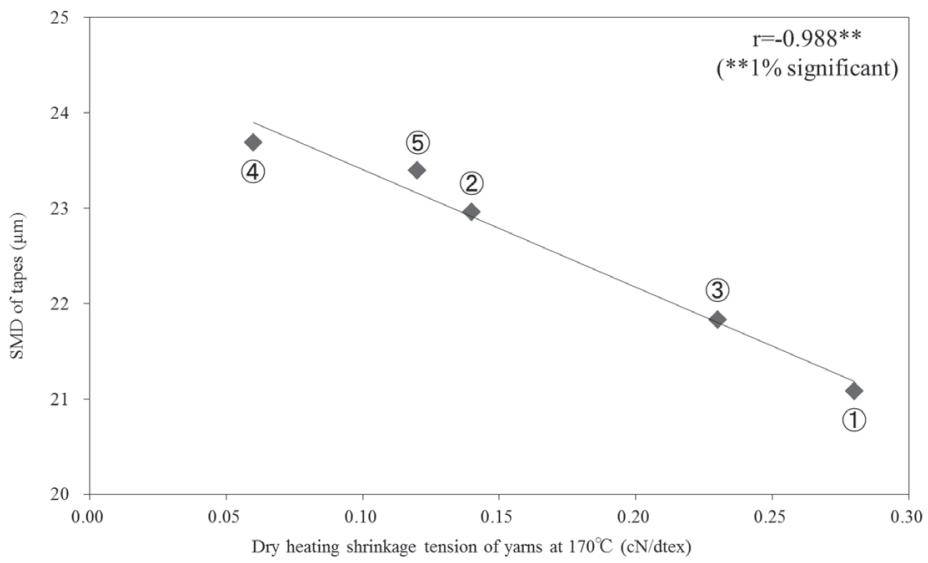

Fig. 3 Relationship between dry heating shrinkage tension of yarns and geometrical roughness (SMD) of tapes. (1) yarn-1, $\mathrm{T}_{1}$ (2)yarn-2, $\mathrm{T}_{2}$ (3)yarn-3, $\mathrm{T}_{3}$ (4)yarn-4, $\mathrm{T}_{4}$ (5) yarn- $5, \mathrm{~T}_{5}$ 
ン編構造糸よりも乾湿感を表す「さらっとした」の手触り評 価および平均摩擦係数 (MIU) に与える影響は小さいことが 明らかになった。これは, Fig. 1 (b) に示すシングルトリコッ 卜編構造糸はFig. 1 (c) に示すシングルサテン編構造糸より も編テープ中央に用いる糸が少ないので, 被験者の手指およ び摩擦子に触れる接触面積が小さかったからと考えられる.

Table 7 より, 粗滑感を表す「滑りやすい」は, 圧縮直線 性（LC）と負の相関（r=-0.962**）がみられたが,「滑りや すい」は試料の表面に手指を滑らせて評価したので, 圧縮直 線性（LC）との相関は疑似相関と考えられる。前節で述べ たように，粗滑感を表す「滑りやすい」に試料差がみられた のは, ヒートセット処理によって各シングルトリコット編構 造糸の乾熱収縮張力が異なり編テープの表面粗さに差異が生 じたからと推測された。 そこで，シングルトリコット編構造 糸（yarn-1 yarn-5）の乾熱収縮張力と試料 $\left(\mathrm{T}_{1} \sim \mathrm{T}_{5}\right)$ の表面粗 さ (SMD) との関係を Fig. 3 に示す.

Fig. 3 より, 乾熱収縮張力と表面粗さ (SMD) には負の相 関 $\left(\mathrm{r}=-0.988^{* *}\right)$ がみられた。このことから，シングルトリ コット編構造糸に乾熱収縮張力が大きい糸（yarn-1 および yarn-3）を用いた試料 $\mathrm{T}_{1}$ および試料 $\mathrm{T}_{3}$ はヒートセット処理 によって表面粗さ（SMD）が小さくなったと考えられる。こ れは, Fig. 1 (d) に示すようにシングルトリコット編構造糸 のシンカーループの両端は鎖編構造糸のシンカーループと交 錯して固定されているので, 乾熱収縮張力が大きいシングル トリコット編構造糸（yarn-1 および yarn-3）のシンカールー プはヒートセット処理によって厚さ方向に対して曲率が小さ くなったからと考えられる

\section{4. 結 言}

本研究では，シングルトリコット編構造糸がファスナ用編 テープの手触りに与える影響を明らかにするために, シング ルトリコット編構造糸だけが異なるファスナ用編テープを作 製して, 被験者が手触り評価を行うとともに各試料の力学特 性を測定し, 手触り評価量と力学特性との相関関係を検討し た。その結果, 得られた知見を以下に示す.
（1）シングルトリコット編構造糸が異なる編テープは, 乾湿 感を表す「さらっとした」および粗滑感を表す「滑りや すい」の手触り評価に影響を与えることがわかった。

(2) 手触り評価された「さらっとした」および「滑りやすい」 と摩擦特性および粗さ特性間には有意な相関がみられな かった。

（3）シングルトリコット編構造糸に伸縮復元率が小さい yarn-1 およびyarn-2 を用いた試料は「さらっとした」と, 伸縮復元率が大きいyarn-4 およびyarn-5 を用いた試料は 「さらっとしていない」と評価されることがわかった。

（4）シングルトリコット編構造糸に乾熱収縮張力が大きい yarn-1 およびyarn-3 を用いた試料は「滑りやすい」と, 乾熱収縮張力が小さい yarn-2 およびy yarn-5 を用いた試料 は「滑りにくい」と評価されることがわかった。

\section{References}

[1] Takehisa F, Nishimatsu T, Kanai H, Kita K, Meiwa M (2016) J Text Eng, 62, 27-36

[2] Takehisa F, Nishimatsu T, Kanai H, Kita K, Meiwa M (2016) J Text Eng, 63, 5-13

[3] Tanaka Y, Hashizume H (2015) Sen'i Gakkaishi, 71, 411-422

[4] Terasaki M, Meda M, Tsubota S (1953) J Text Mach Soc Japan (predecessor jounal of J Text Eng), 11, 729-733

[5] Kawabata S (1970) J Text Mach Soc Japan (predecessor jounal of J Text Eng), 23, 30-35

[6] Yanagawa Y, Kawabata S (1973) J Text Mach Soc Japan (predecessor jounal of J Text Eng), 26, 23-33

[7] Yanagawa Y, Kawabata S (1973) J Text Mach Soc Japan (predecessor jounal of J Text Eng), 26, 179-188

[8] Yanagawa Y, Kawabata S (1975) J Text Mach Soc Japan (predecessor jounal of J Text Eng), 28, 83-92

[9] Yanagawa Y, Kawabata S (1975) J Text Mach Soc Japan (predecessor jounal of J Text Eng), 28, 117-125

[10] Satou S (2008) “Toukeiteki Kannoukensahou”, pp263-270, Nikkagiren

[11] Nishimatsu T, Sakai T (1990) Sen'i Gkkaishi, 46, 265-270 